\title{
Access to self-management education, conservative treatment and surgery for arthritis according to \\ socioeconomic status
}

Ilana N Ackerman (corresponding author): PhD, BPhysio(Hons)

Melbourne EpiCentre

Department of Medicine (Royal Melbourne Hospital)

The University of Melbourne

Parkville Victoria 3050

Australia

Email: i.ackerman@unimelb.edu.au

Phone: +61 383443145

Fax: +61 393428780

Lucy Busija: PhD, MSc, BA(Hons)

Melbourne EpiCentre and Melbourne Brain Centre

Main Block, Royal Melbourne Hospital

Parkville Victoria 3050

Australia

Email: Ibusija@unimelb.edu.au

Phone: +61 393424409

Fax: +61 393428780 


\section{Abstract}

There is now a considerable body of research investigating inequities in access to health care for arthritis according to socioeconomic status (SES). Conducted in a range of settings internationally, studies have examined specific socioeconomic factors (including education, income, deprivation and health insurance status) in relation to access to treatment. This paper provides a comprehensive review of the available evidence on disparities in access to self-management education, conservative therapy and surgical treatment for arthritis, according to SES. There is some evidence of SES disparities in access to self-management education and advice, primary care, specialist care, physical therapy and medications, and strong evidence that people with less education or lower income experience significant disparities in access to joint replacement surgery. In view of research indicating that disparities may adversely affect patient outcomes, examples of initiatives designed to optimise access to care for disadvantaged groups are also described.

\section{Key words}

Arthritis

Arthroplasty

Health Services Accessibility

Patient Education

Social Class

Socioeconomic Factors 


\section{Introduction (A)}

Equitable access to treatment for arthritis is an important goal for clinicians and health policy makers, as delayed access to health care can result in poorer patient outcomes [1-3]. There is now a considerable body of research into disparities in access to treatment for arthritis and this spans a range of demographic factors including gender, race and socioeconomic status (SES). While several review papers have covered disparities in access to joint replacement (arthroplasty), only 2 have included socioeconomic disparities [4,5], although to a limited extent. To our knowledge, there have been no published reviews on disparities in access to arthritis self-management education or conservative management according to SES. This paper aims to provide a comprehensive review of research into access to self-management education, conservative management and surgical treatment for arthritis according to specific socioeconomic factors. 


\section{Methods (A)}

\section{Scope of the review (B)}

For the purpose of this review, SES was initially considered to encompass factors such as education, income and employment. However, additional socioeconomic factors including deprivation, insurance coverage and housing were identified from the search results and were considered relevant to the review. The review was restricted to studies reporting care for arthritis, or for osteoarthritis (OA) or rheumatoid arthritis (RA), being the most common arthritides. As previous reviews have focused specifically on access to joint replacement surgery according to gender and race or ethnicity [5-9], these factors were not evaluated in this paper.

\section{Literature search (B)}

A systematic search of the Cochrane Library, EBSCO CINAHL, EBSCO PsycINFO, Medline (ISI) and PubMed databases was undertaken in March 2012 to identify papers of potential relevance. The final search strategy combined MeSH headings relating to SES, conservative and surgical management and the conditions of interest: "(Social Class or Socioeconomic Factors or Occupations) and (Therapeutics or Drug therapy or Complementary Therapies or Patient Education or Arthroplasty, Replacement or Arthroscopy) and (Arthritis or Osteoarthritis or Arthritis, Rheumatoid) +/- Health Services Accessibility." The search results were pooled $(n=699)$ and screened for relevance. There was no restriction on study type, but papers were excluded if published in a language other than English, or if published prior to 2000 to ensure currency of information. Additional papers of relevance were identified from reference lists and World Wide Web searches. 


\section{Review of relevant literature (B)}

Initial screening revealed substantial variation between studies, in terms of study design, data sources and measures of SES. Meta-analysis techniques were therefore not considered to be appropriate and a narrative review was undertaken. 


\section{Results (A)}

\section{Socioeconomic factors (B)}

The studies reviewed have evaluated a range of socioeconomic factors in relation to access to care for arthritis. These include education, income, occupation and measures of relative socioeconomic disadvantage or deprivation. Deprivation was only reported in studies from the UK, and a variety of measures were used to assess this construct including the Carstairs index, Townsend deprivation score, Scottish Index of Multiple Deprivation, the Index of Multiple Deprivation (England) and the receipt of welfare benefits. A number of studies also used health insurance status as a proxy for SES. Medicaid coverage has been used as a marker of poverty or low income in several studies based in the United States (US), as this program provides means-tested health care funding for people with limited income or resources [10],

\section{Access to self-management education and conservative management (B)}

We identified 28 studies that investigated associations between SES and access to selfmanagement education or conservative management (Table 1). These studies examined access to self-management education and other advice, primary health (general practitioner) care, musculoskeletal specialists (rheumatologists or orthopedic surgeons), allied health services (physical and occupational therapy), medication use and complementary and alternative medicines (CAM).

\section{Arthritis self-management education and provision of advice (C)}

Level of education was the only socioeconomic factor to have been explored in relation to access to arthritis self-management education (both structured and informal). Using data from the US National Health Interview Survey, Hootman et al [11] found that only $5 \%$ of 
those who did not complete high school had received arthritis education, compared with $12 \%$ of those with at least high school education. More recently, a large study in the US involving almost 30,000 people with arthritis found that those who did not complete high school had a lower likelihood of receiving self-management advice from a health professional, compared with college graduates (adjusted odds ratio (OR) 0.81, 95\% confidence interval (Cl) 0.690.95) [12]. In contrast, a study by the developers of the Stanford self-management programs found that level of education was unrelated to participation in arthritis self-management programs in the San Francisco Bay area [13]. However, this study sample is unlikely to be representative of the general population, with an average of 15 years of education and a selfmanagement participation rate of over $42 \%$.

In relation to informal self-management advice, one study found that people with higher education were significantly more likely to receive weight loss advice as a strategy for the management of their arthritis, compared with those who had not completed high school (adjusted ORs 1.19-1.69) [14]. Other studies have reported no relationship between education and receipt of weight loss advice $[11,15]$, regardless of whether or not adjustment was made for body mass index. On the other hand, people with arthritis were found to receive advice on physical activity for arthritis more frequently if they had completed at least high school (57\% vs $49 \%$ for those who did not complete high school) [11].

\section{Primary care (C)}

There is no evidence to suggest that education level is associated with access to primary health care for arthritis. Two studies from the Netherlands involving people with RA found that education was not associated with the utilisation of general practitioner services $[16,17]$. Similarly, a US-based survey of adults with self-reported OA and RA found that access to a 
primary health care practitioner was not associated with education, after adjusting for other factors [18].

Two studies have investigated the association between income and access to primary health care, with contrasting findings. Hagglund et al [18] found that access to primary care was not associated with income, after adjusting for other factors. Conversely, an Italian populationbased study, which included over 25,000 people with arthritis, found significant pro-rich income-related inequities in access to general practitioner services [19]. Two related studies from the United Kingdom (UK) investigating access to knee [20] and hip replacement surgery [21] have found that deprivation (defined as receiving means-tested welfare benefits) was associated with reduced access to general practitioner services among people in need of joint replacement.

Few studies have investigated relationships between other socioeconomic factors and access to primary care. One study from the UK found that people employed in non-manual and manual occupations reported similar utilisation of primary care for knee OA [22]. Similarly, insurance type (public vs private) was not associated with utilisation of general practitioner services for arthritis in studies from the Netherlands [16] or US [18].

\section{Musculoskeletal specialist services (C)}

Although neither education $[16,17]$ nor insurance type [16] was associated with use of rheumatology services among people with RA in studies from the Netherlands, there is evidence of a relationship between SES and access to specialist care in other countries. A Canadian study of people with arthritis and rheumatism found that individuals living in areas with a lower proportion of high school graduates reported less utilisation of musculoskeletal 
specialist services (rheumatologist, orthopaedic surgeon or general internal medicine specialist), after adjusting for other factors including local availability of specialists [23].

Other Canadian research found lower SES to be associated with a longer median time to consultation with a rheumatologist (adjusted hazard ratio $(\mathrm{HR}) 1.16,95 \% \mathrm{Cl} 1.05-1.26)$ [3]. A subsequent qualitative study involving patients with inflammatory arthritis, health professionals and health care administrators reported that lower SES was perceived to be a barrier for access to rheumatology specialists [24]. Masseria et al [19] also reported significant pro-rich income-related inequity in access to specialist services in Italy, and most recently, a Canadian study found the likelihood of consulting an orthopaedic surgeon for OA was greatest for patients in the highest SES quintile, compared with the lowest quintile (adjusted HR for males 1.42, 95\%Cl 1.27-1.58; 1.19, 95\% Cl 1.09-1.31 for females) [25].

Other SES factors have also been associated with delayed access to orthopaedic consultations among people in need of joint replacement surgery. Research involving people undergoing total hip replacement (THR) in England found that individuals whose health care was publicly funded were over 5 times more likely to wait more than 3 months for an orthopaedic outpatient appointment, compared to those with private funding (OR 5.28, $95 \% \mathrm{Cl} 4.22-6.59)[26]$. This study also reported that people who rented public housing were more likely to wait longer for an orthopaedic appointment, compared with people who owned their own home (OR for waiting $>3$ months $1.57,95 \% \mathrm{Cl} 1.31-1.89$ ).

\section{Allied health services (C)}

Preliminary evidence suggests that lower education is associated with greater self-perceived need for physical and occupational therapy [27]. At the same time, there is strong evidence to support a link between lower education and reduced access to allied health services. 
Research from the Netherlands involving people with RA has shown that individuals with a university education were twice as likely to use allied health services, compared with those who had a primary education or less (adjusted OR 2.1, 95\% Cl 1.1-4.0) [16]. A later study involving the same population found even greater disparities in access to allied health services for those with the lowest level of education [17]. A study from the US involving people with musculoskeletal conditions found that those who did not complete high school had a lower likelihood of receiving physical therapy (adjusted OR 0.72, 95\% Cl 0.61-0.86), compared with those who competed high school [28]. In a study of people with RA in the US [29], those with less than college education were only half as likely to have used physical therapy services, compared with those who had higher education (adjusted OR 0.5, 95\% Cl 0.3-0.8).

In their study of people with RA, Iversen et al [29] found that the highest income group was twice as likely to receive physical therapy, compared with lower income groups (adjusted OR 2.0, 95\% $\mathrm{Cl}$ 1.2-3.1). However, no association between income or financial security and access to physical and occupational therapy was found in a US study [27]. The relationship between health insurance status and access to allied health services is also unclear. Research from the Netherlands [16] and US [27] found no relationship between insurance type (private vs public) and utilisation of allied health services for arthritis. However, in another US study, those who had public insurance (adjusted OR $0.66,95 \% \mathrm{Cl} 0.55-0.80$ ) or no health insurance (adjusted OR $0.57,95 \% \mathrm{Cl} 0.43-0.74$ ) were less likely to utilise physical therapy services than those who had private insurance [28]. Similarly, a US study investigating referrals to physical therapy for musculoskeletal conditions found that primary care visits covered by Medicaid were significantly less likely to result in referral to physical therapy, compared with visits covered by private insurance [30]. Insurance status did not affect referrals to physical therapy by orthopaedic surgeons in the same study. 


\section{Medication use (C)}

There is some evidence of disparities in access to medications for arthritis according to SES. Research from North America found that college graduates were more likely to receive tumour necrosis factor inhibitors (TNF-I) for RA, compared with those who had secondary education or less (OR 1.33) [31]. People with private insurance were also more likely to receive TNF-I therapy than those with Medicare or Medicaid cover (OR 1.22) [31]. Lower SES and lower income have also been associated with lower use of disease-modifying antirheumatic drugs (DMARDs) for RA [32]. No relationship was found between occupation category and use of paracetamol or non-steroidal anti-inflammatory medications in knee OA [22].

\section{Complementary and alternative therapies (C)}

There is no clear pattern of SES disparities in access to complementary and alternative therapies. Although one US-based study involving people with OA, RA and fibromyalgia found that higher levels of education were associated with greater CAM use [33], other studies from the US [34,35], as well as those from Korea [36] and Turkey [37] have found no relationship between education and CAM use. Looking at income, some studies have reported an association between higher disposable income [37] or higher annual household income and greater use of CAM among people with arthritis [35], while others have found a negative association [36] or no relationship [33,34]. A study of people with knee OA in the UK reported higher use of both glucosamine and chondroitin supplements by people in nonmanual occupations, compared with those in manual jobs [22]. The same study found no differences in the utilisation of chiropractic or osteopathy services between occupation groups [22]. Two US studies have found that insurance type was not associated with CAM use $[34,35]$. 
There is strong evidence to support a link between lower education and reduced access to allied health services, and some evidence of SES disparities in access to primary care, specialist care, medications and self-management education and advice. There is no clear evidence of a consistent relationship between SES and access to CAM.

\section{Access to arthroscopic surgery (B)}

Only two studies have investigated the relationship between SES and access to knee arthroscopy $[38,39]$. In a retrospective study of patients who received THR, back surgery or arthroscopic knee surgery at 10 Swedish hospitals, Lofvendahl et al [38] found no relationship between education and waiting time for arthroscopy. However, the study sample comprised patients who received arthroscopic surgery for meniscus lesions; it is not known whether they had concomitant arthritis. In a later study, hospital admission databases in England and Canada were used to review rates of first knee arthroscopy among people aged 20 years and over in 1993, 1997, 2002 and 2004 [39]. For both countries, overall rates of arthroscopy were lowest for the lowest income quintile and this pattern was consistent across the 4 time periods. When the analyses were limited to patients who had undergone arthroscopy for OA (excluding those with internal derangement or knee dislocation), those in the lowest income category remained least likely to have had surgery (Canada: 14\% for lowest income quintile vs $23 \%$ for highest quintile; England: $14 \%$ vs $21 \%$ ). We were unable to identify any published studies which investigated access to hip arthroscopy according to SES.

While there is no evidence to suggest disparities in waiting times for knee arthroscopy, socioeconomic disparities in arthroscopy rates have been identified. 


\section{Access to joint replacement surgery (B)}

Most studies investigating access to surgery for arthritis according to SES have focused on joint replacement surgery, namely THR and total knee replacement (TKR). We identified 30 studies that investigated associations between socioeconomic factors and access to joint replacement surgery (Table 2). Access to surgery was most commonly estimated using rates of THR and TKR and/or waiting times for these procedures. Pre-operative wellbeing (for example, HRQoL, clinical status or disease severity) has also been used as a marker of timely or delayed access to surgery. Disparities in access to joint replacement are reported separately for each socioeconomic factor in the following sections, due to the breadth of research in this field.

\section{Level of education (C)}

Several studies have found lower levels of education to be associated with reduced access to joint replacement surgery. Hawker et al [40] conducted a Canadian population-based study to investigate potential unmet need for THR or TKR. Potential unmet need was defined as the proportion of participants with severe arthritis who required joint replacement and was willing to consider surgery, but was not already on a surgical waiting list. They found that people with less education were more likely to need joint replacement and were similarly willing to undergo surgery, resulting in greater potential unmet need for surgery (5.6\%), compared with those who had completed high school (4.5\%) or received postsecondary education (3.4\%). In the US, Melzer et al [41] found that elementary (adjusted OR $0.41,95 \% \mathrm{Cl} 0.24-0.70$ ) and high school education (adjusted OR 0.56, 95\% $\mathrm{Cl}$ 0.36-0.86) were associated with a lower likelihood of having received THR, compared with college education. There was no relationship between education and likelihood of receiving TKR. 
There is also evidence that people with lower education report poorer wellbeing and greater disease severity prior to joint replacement, suggesting possible delayed access to surgery. In an Australian cohort study of people waiting for THR and TKR, Ackerman et al [42] investigated associations between SES and health status at entry to an orthopaedic waiting list. While the majority of participants had poor wellbeing, those with lower education (primary school or less) reported significantly higher psychological distress before surgery. The multinational EUROHIP study involved over 1300 people undergoing primary THR in 12 European countries and found that people without post-school qualifications had greater arthritis severity prior to THR (mean Western Ontario and McMaster Universities Osteoarthritis Index (WOMAC) score $62.2,95 \% \mathrm{Cl} 60.7-63.8)$ than those who had received a postgraduate degree (mean WOMAC 48.9, 95\% Cl 43.3-54.6) [43].

While these studies support a link between lower education and disparities in access to joint replacement, 3 other papers have reported contrasting findings. A Canadian cohort study involving people awaiting THR or TKR concluded that waiting time for surgery was not associated with education [44] but data were not presented to support this finding. Lofvendahl et al [38] also found no significant relationship between education category and waiting time for surgery in their study of over 500 patients undergoing THR in Sweden, although there was a trend towards shorter waits for those with a university degree (median 4.3 months vs 6.0 months for compulsory school education). Most recently, Mnatzaganian et al [45] reported that level of education was not associated with likelihood of having THR or TKR in a cohort of over 11,000 males participating in a male health study in Australia, but these data were not shown. 


\section{Income, wealth and poverty (C)}

There is considerable evidence demonstrating disparities in access to joint replacement surgery according to income, wealth or poverty. Similar to their findings in relation to lower education, Hawker et al [40] also found that individuals in the lowest income category had greater unmet need for joint replacement (proportion with potential unmet need $4.5 \%$ vs $3.5 \%$ for the highest income group). Research by Ackerman et al [42] suggests that even in a public hospital setting, people with lower income may experience delayed access to an orthopaedic waiting list for joint replacement, as indicated by poorer wellbeing at entry to the list. After adjusting for age and sex, people with the lowest annual household income had the poorest HRQoL and the highest psychological distress.

In the English Longitudinal Study of Ageing, researchers found that although need for THR and TKR was highest for individuals in the poorest quintile, compared with the wealthiest quintile (OR $3.23,95 \% \mathrm{Cl} 2.32-4.50)$, the likelihood of having had surgery was similar for the two groups [46]. This indicates inadequate provision of joint replacement for the poorest individuals. However, when contraindications for surgery were included in the model, only the third and fourth quintiles (indicating reduced wealth) had significantly greater need for surgery. The authors concluded that for the poorest individuals, co-morbidities were a major barrier to accessing surgery.

In the US, a national analysis of Medicare claims data showed similar rates of TKR for high and low income quintiles; however, when these data were analysed by region, higher rates of surgery were evident with increasing income [47]. Those in the highest income quintile had the highest rates of TKR, compared with the lowest income quintile (OR 1.19, 95\% Cl 1.171.22). In Italy, a retrospective analysis of hospitalisation data showed that people in the 
lowest income areas were significantly less likely to have THR (standardized rate ratio 0.87 , $95 \% \mathrm{Cl} 0.81-0.95)$, compared with those living in the highest income area [48]. In the US, Bang et al [49] found that people in the lowest income quartile were less likely to have received THR at 2 out of 3 time points, compared with those in the highest income group (OR 0.68, 95\%Cl 0.60-0.77 for year 2000; OR 0.75, 95\%Cl 0.64-0.88 for 2004). However, no consistent pattern was evident for TKR. Also in the US, Hawkins et al [50] found that people with OA living in either a low income or lower medium income area were less likely to receive THR or TKR than those in high income areas (relative risk ratios for income categories 0.89 and 0.95 , respectively).

Only 1 study found no relationship between income and access to THR. In research investigating geographical variation in THR rates across Finland, Makela et al [51] concluded that regional income (estimated using state taxation data) was not associated with incidence of THR; however, these data were not presented.

\section{Deprivation and socioeconomic disadvantage (C)}

There is strong evidence that deprivation and relative socioeconomic disadvantage are associated with disparities in joint replacement provision. In a retrospective analysis of hospital admissions in England, Dixon et al [52] identified a significant deprivation gradient with respect to rates of primary THR, revision THR, primary TKR and revision TKR. For all procedures, rates of surgery were consistently lowest for people in the greatest deprivation quintile, compared with those in the least deprivation quintile.

As part of a population-based survey of over 11,000 people in the UK, Yong et al [20] used the receipt of means-tested welfare benefits to classify deprivation. They found that patients in receipt of benefits were twice as likely to require TKR as those not receiving benefits (after 
excluding individuals with co-morbidities considered unfit for surgery) but no more likely to have had surgery. This group was also less likely to be on a waiting list for TKR. A related publication also found deprivation to be a significant predictor of unmet need for THR [21].

In England, Cookson et al [53] investigated changes in THR utilisation rates from 1991 to 2001. While lower rates of THR persisted among people living in areas with the greatest deprivation, the study also found that differences in utilisation rates between areas of low and high SES had decreased over the 10 -year period (standardized rate ratio $1.41,95 \% \mathrm{Cl} 1.36$ 1.47 for 1991 and $1.27,95 \% \mathrm{Cl} 1.23-1.32$ for 2001). Potential explanations proposed for the observed reduction in SES inequality included overall higher rates of THR, policy changes and altered patterns of arthritis prevalence [53].

In another study from the UK, Judge et al [54] found a small reduction in primary THR rates for the most deprived quintile, compared to the least deprived quintile (adjusted rate ratio $0.94,95 \% \mathrm{Cl} 0.90-0.99)$. However, in a subsequent study, this group reported a marked reduction in provision of primary THR and primary TKR (relative to need) with increasing deprivation [55]. The most deprived quintile had an almost $70 \%$ reduction in access to surgery, compared with the least deprived quintile (equity rate ratio for THR $0.31,95 \% \mathrm{Cl}$ 0.30-0.33; TKR 0.33, 95\% Cl 0.31-0.34).

In Canada, research involving patients recently diagnosed with OA also found that the likelihood of having THR or TKR over the follow-up period (mean 5.5 years) increased significantly with higher SES [25]. The highest SES quintile (indicating highest income neighbourhoods) was most likely to have joint replacement, compared with the lowest quintile (adjusted HR for males 1.52, 95\%Cl 1.26-1.83; 1.34, 95\% Cl 1.16-1.56 for females). In Australia, an analysis of government data showed that people with arthritis living in the 
most disadvantaged quintile were significantly less likely to have a THR, compared with those from the least disadvantaged quintile (age-standardized rate 72.3 vs $83.1 / 100,000$ for males; 76.8 vs 94.0/100,000 for females) [56]. Another Australian study investigating relationships between smoking, body weight, physical activity and risk of THR or TKR found that higher SES (lower socioeconomic disadvantage) was associated with higher rates of joint replacement, although these data were not presented [45].

Only 2 studies have reported increased utilisation of TKR with greater deprivation or disadvantage. In line with earlier research which reported a small increase in TKR rates for those in the most deprived quintile [54], Dixon et al [56] found that people from the most disadvantaged areas were more likely to have a TKR, compared with those from the least disadvantaged quintile (age-standardized rate 109.7 vs 99.5/100,000 for males; 145.4 vs $125.6 / 100,000$ for females). The authors hypothesised this may relate to a higher prevalence of occupational risk factors for knee OA among people from more disadvantaged areas. Only 1 study has found no significant relationship between relative socioeconomic disadvantage and THR utilisation rates [57].

While studies in this area have generally reported consistent patterns in relation to deprivation or socioeconomic disadvantage and joint replacement rates, there is also some evidence to support a relationship between these factors and pre-operative status prior to THR. Studies investigating SES and outcomes of THR in the UK have found that greater deprivation was associated with more severe symptoms pre-operatively [58], poorer preoperative clinical status [59] and worse pre-operative physical and mental health scores [59]. However, a multi-centre prospective study of people undergoing TKR in the UK found no association between deprivation score and pre-operative clinical status or HRQoL [60]. 


\section{Type of health care funding (C)}

Research from the UK and US indicates that access to joint replacement surgery is associated with the type of health care funding. In the UK, the majority of joint replacements are performed within the publicly-funded National Health Service ( $71 \%$ of hip replacements and $72 \%$ of knee replacements in $2010 / 2011$ ), with the remainder undertaken in private or independent hospitals or treatment centres [61]. In a study of patients entering waiting lists for THR in England, those funded publicly were over 12 times more likely to wait 6 months or more for THR (OR 12.80, 95\% CI 9.81-16.68), compared with those who were privately funded [26]. Uniquely capturing the patient's perspective, a qualitative study involving 25 individuals waiting for TKR in the UK found that access to private health care was perceived to enable earlier, inequitable treatment [62]. Two large studies from the US provide further evidence of disparities in access to joint replacement according to health care funding. In an analysis of Medicare claims data, people receiving Medicaid supplements were significantly less likely to have undergone primary or revision THR, compared with those who did not receive supplements (rate ratio $0.66,95 \% \mathrm{Cl} 0.63-0.70$ for primary $\mathrm{THR}$; rate ratio 0.90 , 95\% Cl 0.83-0.97 for revision THR) [63]. Similar findings were also reported for TKR (rate ratio $0.74,95 \% \mathrm{Cl} 0.70-0.78)$ and revision $\operatorname{TKR}(0.89,95 \% \mathrm{Cl} 0.82-0.98)$ in a subsequent paper [64]. Only 1 study has reported contrasting findings; Melzer et al [41] found that people with Medicaid coverage were more likely to have received THR (adjusted OR 1.75, 95\% Cl 1.03-2.97) but not TKR (adjusted OR 1.03, 95\% Cl 0.53-2.02), compared with those who did not have coverage.

\section{Employment (C)}

There has been little research into employment and access to joint replacement. One Canadian study found no relationship between occupation category (classified as manual, non-manual or mixed) and waiting time for THR [65]. Other studies have investigated 
relationships between work status (classified as full-time or other [44], or working versus not working [38]) and waiting for joint replacement, but these classifications may be confounded by factors unrelated to SES. In the multi-centre EUROHIP study, individuals who had retired early had the greatest disease severity before THR (mean WOMAC score 65.3, 95\% CI 61.569.1), compared with those classified as retired (mean 58.8, 95\% Cl 57.3-60.2) or employed (mean 56.7, 95\% Cl 54.6-58.9) [43]. However, the reasons for early retirement were not reported and it is not known whether these relate to SES.

\section{Housing (C)}

There is currently no evidence to suggest a relationship between housing and access to joint replacement surgery. Kelly et al [44] found no association between residence type and waiting time for THR or TKR in Canada, and a study involving people undergoing THR in England found that people who rented public housing had a similar likelihood of waiting 6 months or more for surgery as those who owned their own home [26].

Substantial socioeconomic disparities in the provision of THR and TKR have been reported in a number of countries including Australia, Canada, Italy, UK and the US. Factors most commonly associated with inequitable access to joint replacement surgery include less education, lower income and the type of health care funding. 


\section{Limitations (A)}

Several limitations should be considered in relation to the studies reviewed. Firstly, SES data were not always collected directly from individuals, but often estimated using postcodes or Census data. Secondly, although individual aspects of SES are often reported separately in the literature, factors such as education, income and occupation are undeniably linked. Thirdly, many studies focused on public health sector patients or datasets and did not include people receiving private health care. This could produce biased estimates of the relationship between SES and health care access, since people with higher incomes are more likely to utilise private health systems [52,54]. Finally, reduced rates of health service utilisation including joint replacement are commonly interpreted as evidence of disparities in access to care. However, variation in surgery rates could also be attributed to other factors, as described in the following section. An editorial on gender and ethnic variations in the use of joint replacement questioned the relationship between variation and inequity but concluded with a clear statement: “...if variation represents unequal opportunities to receive effective care, access is inequitable" (p449) [66].

\section{Possible causes of disparities and potential implications (A)}

Although an in-depth analysis of the reasons for SES disparities is beyond the scope of this review, several possible explanations have been proposed in the literature, including:

- individual preferences and willingness to undergo surgery [43,52], although Canadian researchers found no differences in willingness to undergo joint replacement across education or income categories [40];

- limited health literacy or fewer personal resources that would facilitate seeking and accessing health care $[17,24,27,28,66]$;

- financial barriers including health care costs $[13,18,30]$ and loss of income $[47,66]$; 
- the experiences and advice of family members and friends [55,67];

- greater prevalence of co-morbidities contraindicating surgery $[46,48,58]$;

- delays in referral for surgery $[40,59]$;

- $\quad$ protracted waiting times for treatment in public health care settings [57];

- limitations in coverage of specific health services by health insurance plans [16,32]; and

- under-provision of health services in low SES areas [19], although the association between SES and access to health care resources appears to persist after adjusting for local availability of health services [23].

Qualitative research involving both patients and clinicians could improve our understanding of the barriers to equitable health care.

The observed disparities in access to arthritis care are disturbing, particularly in countries with universal health care systems (e.g. Canada) or parallel public and private systems (e.g. Australia and the UK) where demographic factors should not impact on provision of health care. Delays in access to treatment could have important implications, for example, in RA where early initiation of DMARDs can limit joint destruction [3]. For end-stage arthritis, disparities may mean that patients with severe pain or functional impairment do not have equitable access to surgical procedures with demonstrated effectiveness. Additionally, as pre-operative status is the strongest predictor of post-operative outcome from joint replacement $[1,2]$, delayed access to surgery could impact on surgical outcomes. There is preliminary evidence from the UK that deprivation is a significant predictor of relative improvement and outcome following THR $[58,59]$, although further research is needed. 


\section{Initiatives to optimise access to care (A)}

There are few examples in the literature of initiatives or programs designed to optimise access to arthritis care for people of lower SES. One successful initiative is Project ECHO (Extension for Community Healthcare Outcomes), established in New Mexico to improve access to specialist medical care for low income, uninsured or rural patients with hepatitis C [68]. The project has since been expanded to facilitate complex medical care in local communities for other conditions including RA. Partnerships between urban medical specialists and community-based primary care providers enable patients in under-serviced areas to access specialist medical care. Weekly rheumatology teleclinics provide ongoing training and support for primary care providers, building local expertise in the management of rheumatological conditions [69]. Another example is a 'Treatment Decision Support' program which aims to reduce socioeconomic disparities in access to care for patients in the US with Medigap (Medicare supplement) insurance by providing education by telephone and mail about treatment options for hip and knee conditions [50].

Although not limited to arthritis, one example of a government-led initiative to improve access to primary care services is the Medicare Australia bulk billing incentive program [70]. In Australia, doctors can choose whether or not to 'bulk bill' patients, whereby the government directly pays doctors a set fee for the consultation, with no out-of-pocket costs borne by the patient. The incentive program was introduced in 2004 and offers additional payments to general practitioners who bulk bill patients with concession cards (available to people on low incomes or those who receive welfare support). This program has not been extended to include medical specialists, although this could alleviate the financial burden of accessing specialist care for those with fewer resources [71]. 
Other initiatives have been introduced by professional organisations in the US to improve understanding of SES and related issues. For example, the New Jersey Chapter of the National Association of Social Workers stipulates that social workers must complete mandatory continuing education in social and cultural competence, which can include issues relating to SES and education [72]. Another example is a national training program for community cancer organisations (the Socioeconomic Status Related Cancer Disparities Program), which is being implemented by the American Psychological Association to address socioeconomic disparities in cancer prevention and control [73]. Although some US states now mandate that physicians complete courses in cultural competency (focusing on racial and ethnic disparities) as a licensing requirement [74], we did not find any similar examples for SES disparities.

Word count (including references): $\mathbf{7 8 2 9}$ 


\section{Summary}

This paper has reviewed the current evidence on socioeconomic disparities in access to selfmanagement education, conservative management and surgical treatment for arthritis. The review shows that relationships between lower SES and reduced access to care or lower utilisation of health services exist in many settings internationally. There is evidence that factors such as education, income or deprivation are associated with disparities in access to self-management education or advice, primary care, specialist care, physical therapy and medications. Inequities in the provision of knee arthroscopy have been observed in Canada and the UK, while considerable disparities in access to THR and TKR have been reported in a number of countries including Australia, Canada, Italy, UK and the US. A range of potential contributing factors has been proposed in the literature, including patient preferences, financial barriers, delays in referral for treatment, lengthy waiting times for services in public health systems and under-provision of services in low SES areas. Further research involving both patients and clinicians will assist in improving our understanding of the barriers to equitable service provision. There are also preliminary data from the UK which indicate that lower SES is associated with poorer outcomes following THR. Given the potential impact of reduced or delayed access to treatment on patient outcomes, ensuring timely and equitable arthritis care for those with fewer socioeconomic resources is imperative. 


\section{Practice points}

- There is some evidence of disparities in access to self-management education, primary care, specialist care, physical therapy and RA medications, according to factors such as education and income

- There is a large body of evidence to indicate that socioeconomic disparities exist internationally in access to joint replacement surgery

- There is preliminary evidence that lower SES is a predictor of poorer outcome from total hip replacement surgery

\section{Research agenda}

- Qualitative research involving both patients and clinicians could improve our understanding of the barriers to accessing treatment for arthritis

- Further investigation is needed to determine the impact of the observed disparities on patient outcomes in arthritis 


\section{References}

[1] Fortin PR, Penrod JR, Clarke AE et al. Timing of total joint replacement affects clinical outcomes among patients with osteoarthritis of the hip or knee. Arthritis Rheum 2002;46: 3327-30.

[2] Lingard EA, Katz JN, Wright EA et al. Predicting the outcome of total knee arthroplasty. J Bone Joint Surg 2004;86A: 2179-86.

*[3] Feldman DE, Bernatsky S, Haggerty J et al. Delay in consultation with specialists for persons with suspected new-onset rheumatoid arthritis: A population-based study. Arthritis Care Res 2007;57: 1419-25.

[4] Ellis H, Bucholz R. Disparity of care in total hip arthroplasty. Curr Opin Orthop 2007;18: 2-7.

[5] Singh JA. Epidemiology of knee and hip arthroplasty: A systematic review. Open Orthop J 2011;5: 80-5.

[6] Kane RL, Wilt T, Suarez-Almazor ME et al. Disparities in total knee replacements: A review. Arthritis Care Res 2007;57: 562-7.

[7] Ibrahim SA. Racial variations in the utilization of knee and hip joint replacement: An introduction and review of the most recent literature. Curr Orthop Pract 2010;21: 12631.

[8] Irgit K, Nelson CL. Defining racial and ethnic disparities in THA and TKA. Clin Orthop 2011;469: 1817-23.

[9] Novicoff WM, Saleh KJ. Examining sex and gender disparities in total joint arthroplasty. Clin Orthop 2011;469: 1824-8.

[10] Centers for Medicare and Medicaid Services. Medicaid.gov. Keeping America healthy. Available from: http://www.medicaid.govl. Accessed 24 July 2012. 
[11] Hootman JM, Langmaid G, Helmick CG et al. Monitoring progress in arthritis management - United States and 25 States, 2003. MMWR Morb Mortal Wkly Rep 2005;54: 484-8.

[12] Carlson SA, Maynard LM, Fulton JE et al. Physical activity advice to manage chronic conditions for adults with arthritis or hypertension, 2007. Prev Med 2009;49: 209-12.

[13] Bruce B, Lorig K, Laurent D. Participation in patient self-management programs. Arthritis Rheum 2007;57: 851-4.

[14] Fontaine KR, Haaz S, Bartlett SJ. Are overweight and obese adults with arthritis being advised to lose weight? J Clin Rheumatol 2007;13: 12-15.

[15] Mehrotra C, Naimi TS, Serdula M et al. Arthritis, body mass index, and professional advice to lose weight: Implications for clinical medicine and public health. Am J Prev Med 2004;27: 16-21.

*[16] Jacobi CE, Triemstra M, Rupp I et al. Health care utilization among rheumatoid arthritis patients referred to a rheumatology center: Unequal needs, unequal care? Arthritis Rheum 2001;45: 324-30.

[17] Jacobi CE, Mol GD, Boshuizen HC et al. Impact of socioeconomic status on the course of rheumatoid arthritis and on related use of health care services. Arthritis Care Res 2003;49: 567-73.

*[18] Hagglund KJ, Clark MJ, Hilton SA et al. Access to healthcare services among persons with osteoarthritis and rheumatoid arthritis. Am J Phys Med Rehabil 2005;84: 702-11.

*[19] Masseria C, Giannoni M. Equity in access to health care in Italy: A disease-based approach. Eur J Public Health 2010;20: 504-10.

[20] Yong PF, Milner PC, Payne JN et al. Inequalities in access to knee joint replacements for people in need. Ann Rheum Dis 2004;63: 1483-9.

[21] Milner PC, Payne JN, Stanfield RC et al. Inequalities in accessing hip joint replacement for people in need. Eur J Public Health 2004;14: 58-62. 
[22] Jordan KM, Sawyer S, Coakley P et al. The use of conventional and complementary treatments for knee osteoarthritis in the community. Rheumatology 2004;43: 381-4.

[23] Boyle E, Badley EM, Glazier RH. The relationship between local availability and firsttime use of specialists in an arthritis population. Can J Public Health 2006;97: 210-13.

[24] Bernatsky S, Feldman DE, Dawes $M$ et al. Clarifying the barriers to optimal healthcare for persons with inflammatory arthritis. J Rheumatol 2009;36: 852.

*[25] Rahman MM, Kopec JA, Sayre EC et al. Effect of sociodemographic factors on surgical consultations and hip or knee replacements among patients with osteoarthritis in British Columbia, Canada. J Rheumatol 2011;38: 503-9.

[26] Fitzpatrick R, Norquist JM, Reeves BC et al. Equity and need when waiting for total hip replacement surgery. J Eval Clin Pract 2004;10: 3-9.

[27] Feldman DE, Bernatsky S, Lévesque JF et al. Access and perceived need for physical and occupational therapy in chronic arthritis. Disabil Rehabil 2010;32: 1827-32.

[28] Carter SK, Rizzo JA. Use of outpatient physical therapy services by people with musculoskeletal conditions. Phys Ther 2007;87: 497-512.

[29] Iversen MD, Chhabriya RK, Shadick N. Predictors of the use of physical therapy services among patients with rheumatoid arthritis. Phys Ther 2011;91: 65-76.

[30] Freburger JK, Holmes GM, Carey TS. Physician referrals to physical therapy for the treatment of musculoskeletal conditions. Arch Phys Med Rehabil 2003;84: 1839-49.

[31] Lee SJ, Kremer J, Kavanaugh A. Treatment disparity related to race/ethnicity and education in rheumatoid arthritis patients: Comment on the article by Constantinescu et al. Arthritis Care Res 2009;61: 1141-2.

*[32] Schmajuk G, Trivedi AN, Solomon DH et al. Receipt of disease-modifying antirheumatic drugs among patients with rheumatoid arthritis in Medicare managed care plans. JAMA 2011;305: 480-6. 
[33] Herman CJ, Allen P, Hunt WC et al. Use of complementary therapies among primary care clinic patients with arthritis. Prev Chronic Dis 2004;1: 1-15.

[34] Kaboli PJ, Doebbeling BN, Saag KG et al. Use of complementary and alternative medicine by older patients with arthritis: A population-based study. Arthritis Rheum 2001;45: 398-403.

[35] Quandt SA, Chen H, Grzywacz JG et al. Use of complementary and alternative medicine by persons with arthritis: Results of the National Health Interview Survey. Arthritis Rheum 2005;53: 748-55.

[36] Kim HA, Seo YI. Use of complementary and alternative medicine by arthritis patients in a university hospital clinic serving rheumatology patients in Korea. Rheumatol Int 2003;23: 277-81.

[37] Ünsal A, Gözüm S. Use of complementary and alternative medicine by patients with arthritis. J Clin Nurs 2010;19: 1129-38.

[38] Lofvendahl S, Eckerlund I, Hansagi $\mathrm{H}$ et al. Waiting for orthopaedic surgery: Factors associated with waiting times and patients' opinion. Int J Qual Health Care 2005;17: 133-40.

[39] Hawker G, Guan J, Judge A et al. Knee arthroscopy in England and Ontario: Patterns of use, changes over time, and relationship to total knee replacement. $\underline{\mathrm{J} \text { Bone Joint }}$ Surg 2008;90A: 2337-45.

*[40] Hawker GA, Wright JG, Glazier RH et al. The effect of education and income on need and willingness to undergo total joint arthroplasty. Arthritis Rheum 2002;46: 3331-9.

[41] Melzer D, Guralnik JM, Brock D. Prevalence and distribution of hip and knee joint replacements and hip implants in older Americans by the end of life. Aging Clin Exp Res 2003;15: 60-6. 
[42] Ackerman IN, Graves SE, Wicks IP et al. Severely compromised quality of life in women and those of lower socioeconomic status waiting for joint replacement surgery. Arthritis Care Res 2005;53: 653-8.

[43] Dieppe $P$, Judge A, Williams S et al. Variations in the pre-operative status of patients coming to primary hip replacement for osteoarthritis in European orthopaedic centres. BMC Musculoskelet Disord 2009;10: 19.

[44] Kelly KD, Voaklander DC, Johnston WC et al. Equity in waiting times for major joint arthroplasty. Can J Surg 2002;45: 269-76.

[45] Mnatzaganian G, Ryan P, Norman PE et al. Reply. Arthritis Rheum 2012;64: 1300-1.

[46] Steel N, Melzer D, Gardener E et al. Need for and receipt of hip and knee replacement - A national population survey. Rheumatology 2006;45: 1437-41.

[47] Skinner J, Zhou W, Weinstein J. The influence of income and race on total knee arthroplasty in the United States. J Bone Joint Surg 2006;88A: 2159-66.

[48] Agabiti N, Picciotto S, Cesaroni G et al. The influence of socioeconomic status on utilization and outcomes of elective total hip replacement: A multicity population-based longitudinal study. Int J Qual Health Care 2007;19: 37-44.

[49] Bang H, Chiu YL, Memtsoudis SG et al. Total hip and total knee arthroplasties: Trends and disparities revisited. Am J Orthop 2010;39: E95-102.

[50] Hawkins K, Escoto KH, Ozminkowski RJ et al. Disparities in major joint replacement surgery among adults with Medicare supplement insurance. Popul Health Manag 2011;14: 231-8.

[51] Makela KT, Peltola M, Hakkinen U et al. Geographical variation in incidence of primary total hip arthroplasty: A population-based analysis of 34,642 replacements. $\underline{\text { Arch }}$ Orthop Trauma Surg 2010;130: 633-9.

*[52] Dixon T, Shaw M, Ebrahim S et al. Trends in hip and knee joint replacement: Socioeconomic inequalities and projections of need. Ann Rheum Dis 2004;63: 825-30. 
[53] Cookson R, Dusheiko M, Hardman G. Socioeconomic inequality in small area use of elective total hip replacement in the English National Health Service in 1991 and 2001. J Health Serv Res Policy 2007;12: S1:10-17.

[54] Judge A, Welton NJ, Sandhu J et al. Geographical variation in the provision of elective primary hip and knee replacement: The role of socio-demographic, hospital and distance variables. J Public Health 2009;31: 413-22.

*[55] Judge A, Welton NJ, Sandhu J et al. Equity in access to total joint replacement of the hip and knee in England: Cross sectional study. BMJ 2010;341:c4092 doi:10.1136/bmj.c4092.

_[56] Dixon T, Urquhart DM, Berry $\mathrm{P}$ et al. Variation in rates of hip and knee joint replacement in Australia based on socio-economic status, geographical locality, birthplace and indigenous status. ANZ J Surg 2011;81: 26-31.

[57] Brennan S, Stanford T, Wluka A et al. Cross-sectional analysis of association between socioeconomic status and utilization of primary total hip joint replacements 2006-7: Australian Orthopaedic Association National Joint Replacement Registry. BMC Musculoskelet Disord 2012;13: 63.

[58] Clement ND, Muzammil A, Macdonald D et al. Socioeconomic status affects the early outcome of total hip replacement. J Bone Joint Surg 2011;93B: 464-9.

[59] Jenkins PJ, Perry PR, Yew Ng C et al. Deprivation influences the functional outcome from total hip arthroplasty. Surgeon 2009;7: 351-6.

[60] Murray JR, Birdsall PD, Sher JL et al. Deprivation and outcome of total knee replacement. Knee 2006;13: 98-101.

[61] National Joint Registry. National Joint Registry for England and Wales 8th annual report 2011. Available from: http://www.njrcentre.org.uk/NjrCentre/Portals/0/Documents/NJR\%208th\%20Annual\%2 OReport\%202011.pdf. Accessed 24 July 2012. 
[62] Woolhead GM, Donovan JL, Chard JA et al. Who should have priority for a knee joint replacement? Rheumatology 2002;41: 390-4.

*[63] Mahomed NN, Barrett JA, Katz JN et al. Rates and outcomes of primary and revision total hip replacement in the United States Medicare population. J Bone Joint Surg 2003;85A: 27-32.

[64] Mahomed NN, Barrett J, Katz JN et al. Epidemiology of total knee replacement in the United States Medicare population. J Bone Joint Surg 2005;87 A: 1222-8.

[65] Gaudet MC, Ehrmann Feldman D, Rossignol M et al. The wait for total hip replacement in patients with osteoarthritis. Can J Surg 2007;50: 101-9.

[66] Suarez-Almazor ME. Unraveling gender and ethnic variation in the utilization of elective procedures: The case of total joint replacement. Med Care 2002;40: 447-50.

[67] Hawker GA. Who, when, and why total joint replacement surgery? The patient's perspective. Curr Opin Rheumatol 2006;18: 526-30.

[68] Arora S, Kalishman S, Dion D et al. Partnering urban academic medical centers and rural primary care clinicians to provide complex chronic disease care. Health Aff 2011;30: 1176-84.

[69] The University of New Mexico. Rheumatology TeleECHO Clinic. Available from: http://echo.unm.edu/clinics/clinic-rheumatology.html. Accessed 5 June 2012.

[70] Medicare Australia. Incentive payments to GPs who bulk bill concessional patients and children aged under 16 years. Available from: http://www.medicareaustralia.gov.au/provider/incentives/files/incentive payments to G Ps who bulk bill concessional patients under 16.pdf. Accessed 24 July 2012.

[71] Usherwood TP. Private specialist practice: The forgotten sector in health care reform. Med J Aust 2012;196: 235-6.

[72] National Association of Social Workers - New Jersey Chapter. Licensing - Social and cultural competence requirement. Available from: http://www.nasw- 
nj.affiniscape.com/displaycommon.cfm?an=1\&subarticlenbr=187. Accessed 24 July 2012.

[73] American Psychological Association. Socioeconomic Status Related Cancer Disparities Program (SESRCD). Available from:

http://www.apa.org/pi/ses/programs/index.aspx?tab=4. Accessed 24 July 2012.

[74] Landers SJ. Mandating cultural competency: Should physicians be required to take courses? Am Med News 2009. Available from http://www.amaassn.org/amednews/2009/10/19/prsa1019.htm. Accessed 24 July 2012.

[75] Mnatzaganian G, Ryan P, Norman PE et al. Smoking, body weight, physical exercise, and risk of lower limb total joint replacement in a population-based cohort of men. Arthritis Rheum 2011;63: 2523-30. 


\section{Conflict of interest statement}

There are no conflicts of interest to declare.

\section{Acknowledgments}

Dr Ackerman is supported by a National Health and Medical Research Council of Australia Public Health (Australian) Early Career Fellowship (\#520004). Dr Busija is supported by a postdoctoral fellowship jointly funded by the Melbourne EpiCentre and the Centre for Research Excellence in Translational Neuroscience (Royal Melbourne Hospital and The University of Melbourne). 


\section{Table 1. Research studies investigating access to self-management education and conservative management according to socioeconomic status}

\begin{tabular}{|c|c|c|c|c|c|}
\hline Authors & Design & Country & Type of service & Study population / dataset(s) used & Summary of findings \\
\hline $\begin{array}{l}\text { Bernatsky et al } \\
\text { (2009) [24] }\end{array}$ & $\begin{array}{l}\text { Qualitative } \\
\text { study (focus } \\
\text { groups) }\end{array}$ & Canada & Rheumatology specialist & $\begin{array}{l}\text { Patients with inflammatory arthritis, health } \\
\text { care practitioners, and administrative health } \\
\text { care decision-makers (total sample size not } \\
\text { specified) }\end{array}$ & $\begin{array}{l}\text { Lower SES was identified as a } \\
\text { barrier for access to rheumatology } \\
\text { specialists. }\end{array}$ \\
\hline $\begin{array}{l}\text { Boyle et al } \\
(2006)[23]\end{array}$ & $\begin{array}{l}\text { Prospective } \\
\text { cohort study }\end{array}$ & Canada & $\begin{array}{l}\text { Musculoskeletal } \\
\text { specialists: } \\
\text { rheumatologists, } \\
\text { orthopaedic surgeons and } \\
\text { general internal medicine } \\
\text { specialists }\end{array}$ & $\begin{array}{l}\text { Individuals aged } \geq 15 \text { years with self-reported } \\
\text { arthritis and rheumatism, who also consulted } \\
\text { a health care professional for their condition, } \\
\text { identified from the } 1996 / 1997 \text { Ontario Health } \\
\text { Survey }(n=5,052)\end{array}$ & $\begin{array}{l}\text { Individuals residing in an area with a } \\
\text { lower proportion of high school } \\
\text { graduates were less likely to seek } \\
\text { consultation with musculoskeletal } \\
\text { specialist for their condition. }\end{array}$ \\
\hline $\begin{array}{l}\text { Bruce et al } \\
\text { (2007) [13] }\end{array}$ & $\begin{array}{l}\text { Cross-sectional } \\
\text { study }\end{array}$ & US & $\begin{array}{l}\text { Arthritis self-management } \\
\text { education }\end{array}$ & $\begin{array}{l}\text { Adults with arthritis participating in a life-long } \\
\text { follow up Arthritis, Rheumatism, and Aging } \\
\text { Medical Information Systems study ( } n=619)\end{array}$ & $\begin{array}{l}\text { Participation in arthritis self- } \\
\text { management programs was not } \\
\text { related to the number of years of } \\
\text { education. }\end{array}$ \\
\hline $\begin{array}{l}\text { Carlson et al } \\
\text { (2009) [12] }\end{array}$ & $\begin{array}{l}\text { Population- } \\
\text { based survey }\end{array}$ & US & $\begin{array}{l}\text { Arthritis self-management } \\
\text { education }\end{array}$ & $\begin{array}{l}\text { Individuals with arthritis sourced from the } \\
2007 \text { Behavioural Risk Factor Surveillance } \\
\text { System }(n=29,698) \text {. }\end{array}$ & $\begin{array}{l}\text { Lower education was associated } \\
\text { with not receiving self-management } \\
\text { advice from a health professional. }\end{array}$ \\
\hline $\begin{array}{l}\text { Carter and } \\
\text { Rizzio (2007) } \\
\text { [28] }\end{array}$ & $\begin{array}{l}\text { Population- } \\
\text { based survey }\end{array}$ & US & Physical therapy & $\begin{array}{l}\text { Non-institutionalised civilians with a } \\
\text { medically diagnosed musculoskeletal } \\
\text { condition, who took part in the Medial } \\
\text { Expenditure Panel Survey between } 1996 \\
\text { and } 2000(n=18,546)\end{array}$ & $\begin{array}{l}\text { Higher levels of education and } \\
\text { having private health insurance } \\
\text { were associated with a higher } \\
\text { probability of receiving a physical } \\
\text { therapy service. }\end{array}$ \\
\hline $\begin{array}{l}\text { Feldman et al } \\
\text { (2007) [3] }\end{array}$ & $\begin{array}{l}\text { Retrospective } \\
\text { analysis }\end{array}$ & Canada & Rheumatology specialist & $\begin{array}{l}\text { Incident RA patients diagnosed by a non- } \\
\text { rheumatology specialist identified from } \\
\text { physician reimbursement administrative data } \\
\text { set for the state of Quebec }(n=10,001)\end{array}$ & $\begin{array}{l}\text { Lower SES was associated with } \\
\text { longer median time from initial visit } \\
\text { to a physician to consultation with a } \\
\text { rheumatologist. }\end{array}$ \\
\hline $\begin{array}{l}\text { Feldman et al } \\
(2010)[27]\end{array}$ & $\begin{array}{l}\text { Cross-sectional } \\
\text { study }\end{array}$ & Canada & $\begin{array}{l}\text { Physical and occupational } \\
\text { therapy }\end{array}$ & $\begin{array}{l}\text { Individuals with physician-confirmed arthritis } \\
\text { recruited from primary care clinics in Quebec } \\
(n=211)\end{array}$ & $\begin{array}{l}\text { Higher perceived need for physical } \\
\text { or occupational therapy was } \\
\text { associated with having college or } \\
\text { university education but not income } \\
\text { or financial security. }\end{array}$ \\
\hline $\begin{array}{l}\text { Fitzpatrick et al } \\
\text { (2004) [26] }\end{array}$ & $\begin{array}{l}\text { Cross-sectional } \\
\text { study }\end{array}$ & UK & Orthopaedic surgeon & $\begin{array}{l}\text { Patients undergoing THR in } 5 \text { English health } \\
\text { regions between } 1996 \text { and } 1997(13,343 \\
\text { procedures) }\end{array}$ & $\begin{array}{l}\text { Public patients were over } 5 \text { times } \\
\text { more likely to wait }>3 \text { months for an } \\
\text { orthopaedic outpatient appointment. }\end{array}$ \\
\hline
\end{tabular}




\begin{tabular}{|c|c|c|c|c|c|}
\hline Authors & Design & Country & Type of service & Study population / dataset(s) used & Summary of findings \\
\hline & & & & & $\begin{array}{l}\text { People renting public housing were } \\
\text { also more likely to have longer } \\
\text { outpatient waits than those who } \\
\text { owned their own home. }\end{array}$ \\
\hline $\begin{array}{l}\text { Fontaine et al } \\
\text { (2007) [14] }\end{array}$ & $\begin{array}{l}\text { Population- } \\
\text { based survey }\end{array}$ & US & Weight loss advice & $\begin{array}{l}\text { Data from the } 2002 \text { Behavioural Risk Factor } \\
\text { Surveillance System }(n=31,165)\end{array}$ & $\begin{array}{l}\text { Among overweight or obese } \\
\text { individuals with arthritis, higher level }\end{array}$ \\
\hline $\begin{array}{l}\text { Freburger et al } \\
(2003)[30]\end{array}$ & $\begin{array}{l}\text { Cross-sectional } \\
\text { study }\end{array}$ & US & Physical therapy & $\begin{array}{l}\text { National Ambulatory Medical Care Survey } \\
(1995-1999) \text { ( } n=4,911 \text { for primary care visits; } \\
n=4,207 \text { for orthopaedic surgeon visits) }\end{array}$ & $\begin{array}{l}\text { Primary care visits covered by } \\
\text { Medicaid were less likely to result in } \\
\text { referral for physical therapy than } \\
\text { visits covered by private insurance. }\end{array}$ \\
\hline $\begin{array}{l}\text { Hagglund et al } \\
\text { (2005) [18] }\end{array}$ & $\begin{array}{l}\text { Cross-sectional } \\
\text { study }\end{array}$ & US & $\begin{array}{l}\text { Primary health care } \\
\text { practitioner }\end{array}$ & $\begin{array}{l}\text { People aged } \geq 18 \text { years with self-reported } \\
\text { OA or RA recruited through community and } \\
\text { web-based advertising ( } n=409)\end{array}$ & $\begin{array}{l}\text { Access to a primary health care } \\
\text { practitioner was not associated with } \\
\text { education, income or health care } \\
\text { plan. }\end{array}$ \\
\hline $\begin{array}{l}\text { Herman et at } \\
\text { (2004) [33] }\end{array}$ & $\begin{array}{l}\text { Cross-sectional } \\
\text { study }\end{array}$ & US & CAM & $\begin{array}{l}\text { Individuals aged } 18-84 \text { years diagnosed } \\
\text { with OA, RA, or fibromyalgia who attended a } \\
\text { primary care clinic at the University of New } \\
\text { Mexico (June } 2000 \text {-May 2001) }(n=612)\end{array}$ & $\begin{array}{l}\text { Greater use of CAM was associated } \\
\text { with higher level of education but } \\
\text { not income. }\end{array}$ \\
\hline $\begin{array}{l}\text { Hootman et al } \\
(2005)[11]\end{array}$ & $\begin{array}{l}\text { Population- } \\
\text { based survey }\end{array}$ & US & $\begin{array}{l}\text { Weight loss advice } \\
\text { Physical activity advice } \\
\text { Arthritis education }\end{array}$ & $\begin{array}{l}\text { People aged } \geq 18 \text { years with self-reported } \\
\text { doctor-diagnosed arthritis identified from the } \\
2003 \text { National Health Interview Survey (total } \\
\text { sample size not specified) }\end{array}$ & $\begin{array}{l}\text { Lower education was associated } \\
\text { with less physical activity advice but } \\
\text { not with weight loss advice. }\end{array}$ \\
\hline $\begin{array}{l}\text { Iversen et al } \\
\text { (2011) [29] }\end{array}$ & $\begin{array}{l}\text { Prospective } \\
\text { cohort study }\end{array}$ & US & Physical therapy & $\begin{array}{l}\text { Adults with RA recruited from a hospital- } \\
\text { based registry }(n=772)\end{array}$ & $\begin{array}{l}\text { Lower education and lower income, } \\
\text { but not health insurance status, } \\
\text { were associated with less use of } \\
\text { physical therapy services. }\end{array}$ \\
\hline \multirow[t]{2}{*}{$\begin{array}{l}\text { Jacobi et al } \\
(2001)[16]\end{array}$} & $\begin{array}{l}\text { Cross-sectional } \\
\text { study }\end{array}$ & Netherlands & $\begin{array}{l}\text { General practitioner } \\
\text { Medical specialist } \\
\text { Allied health services }\end{array}$ & $\begin{array}{l}\text { Adults with RA referred to a rheumatology } \\
\text { centre }(n=725)\end{array}$ & $\begin{array}{l}\text { Low levels of education were } \\
\text { associated with less use of allied } \\
\text { health care but not with the use of } \\
\text { other health care services. }\end{array}$ \\
\hline & & & & & $\begin{array}{l}\text { Insurance type was not associated } \\
\text { with utilisation of general } \\
\text { practitioner, medical specialist or }\end{array}$ \\
\hline
\end{tabular}




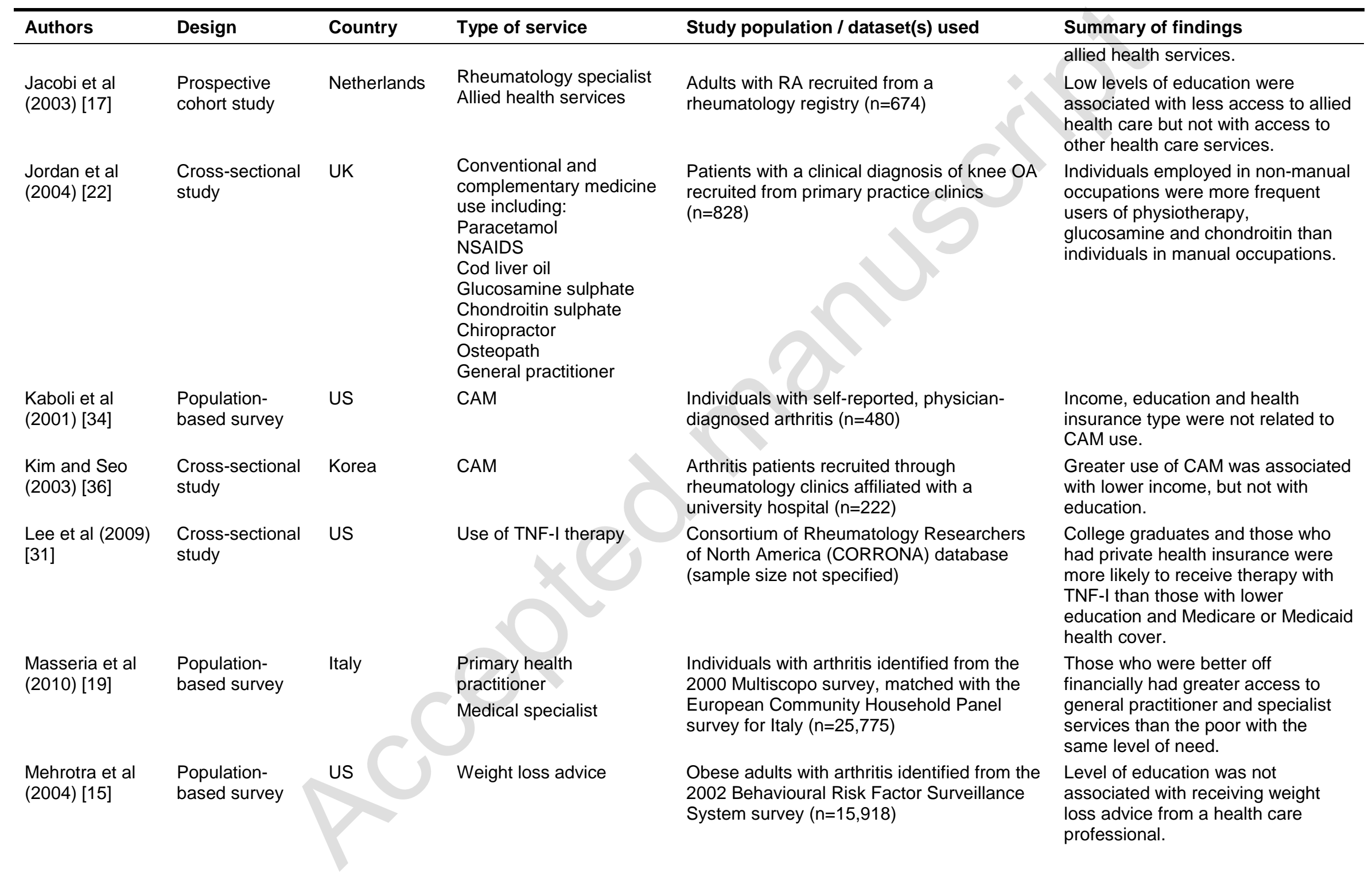




\begin{tabular}{|c|c|c|c|c|c|}
\hline Authors & Design & Country & Type of service & Study population / dataset(s) used & Summary of findings \\
\hline $\begin{array}{l}\text { Milner et al } \\
(2004) \text { [21] }\end{array}$ & $\begin{array}{l}\text { Population- } \\
\text { based study }\end{array}$ & UK & General practitioner & $\begin{array}{l}\text { People aged } \geq 65 \text { years from } 2 \text { Health } \\
\text { Authority regions ( } n=11,214 \text { ) including } 388 \\
\text { individuals in need of hip replacement }\end{array}$ & $\begin{array}{l}\text { Socioeconomic deprivation was } \\
\text { associated with less use of primary } \\
\text { practitioner services. }\end{array}$ \\
\hline $\begin{array}{l}\text { Quandt et al } \\
\text { (2005) [35] }\end{array}$ & $\begin{array}{l}\text { Population- } \\
\text { based survey }\end{array}$ & US & CAM & $\begin{array}{l}\text { Individuals with arthritis identified from the } \\
2002 \text { National Health Interview Survey } \\
(n=9,655)\end{array}$ & $\begin{array}{l}\text { Greater use of CAM was associated } \\
\text { with lower income, but not with } \\
\text { education or insurance type. }\end{array}$ \\
\hline $\begin{array}{l}\text { Rahman et al } \\
\text { (2011) [25] }\end{array}$ & $\begin{array}{l}\text { Prospective } \\
\text { cohort study }\end{array}$ & Canada & Orthopaedic surgeon & $\begin{array}{l}\text { Patients newly diagnosed with OA from } \\
1996 \text { to } 1998 \text { in British Columbia }(n=34,420)\end{array}$ & $\begin{array}{l}\text { People residing in areas with the } \\
\text { highest SES were most likely to see } \\
\text { an orthopaedic surgeon for OA } \\
\text { during the } 8 \text { years of follow-up. }\end{array}$ \\
\hline $\begin{array}{l}\text { Schmajuk et al } \\
\text { (2011) [32] }\end{array}$ & $\begin{array}{l}\text { Population- } \\
\text { based survey }\end{array}$ & US & DMARDs & $\begin{array}{l}\text { Patients with RA aged } \geq 65 \text { years identified } \\
\text { from the } 2005 \text { Healthcare Effectiveness } \\
\text { Data and Information Set }(n=93,143)\end{array}$ & $\begin{array}{l}\text { Low personal income and residing } \\
\text { in an area with lower SES status } \\
\text { was associated with less use of } \\
\text { DMARDs. }\end{array}$ \\
\hline $\begin{array}{l}\text { Ünsal and } \\
\text { Gözüm (2010) } \\
\text { [37] }\end{array}$ & $\begin{array}{l}\text { Cross-sectional } \\
\text { study }\end{array}$ & Turkey & CAM & $\begin{array}{l}\text { Patients with arthritis attending } \\
\text { physiotherapy and immunology clinics } \\
(n=250)\end{array}$ & $\begin{array}{l}\text { Higher frequency of CAM use was } \\
\text { associated with higher disposable } \\
\text { income but not with education. }\end{array}$ \\
\hline $\begin{array}{l}\text { Yong et al } \\
(2004) \text { [20] }\end{array}$ & $\begin{array}{l}\text { Cross-sectional } \\
\text { population- } \\
\text { based study } \\
\text { with follow-up } \\
\text { healthcare data } \\
\text { linkage }\end{array}$ & UK & General practitioner & $\begin{array}{l}\text { People aged } \geq 65 \text { years from } 2 \text { Health } \\
\text { Authority regions }(n=11,214) \text { including } 574 \\
\text { individuals in need of knee replacement }\end{array}$ & $\begin{array}{l}\text { People living in areas of greater } \\
\text { deprivation were less likely to be } \\
\text { utilising general practitioner } \\
\text { services. }\end{array}$ \\
\hline
\end{tabular}

CAM: complementary and alternative medicines; DMARD: disease-modifying antirheumatic drug; NSAID: non-steroidal anti-inflammatory drug; OA: osteoarthritis; RA: rheumatoid arthritis; SES: socioeconomic status; TNF-I: tumour necrosis factor inhibitor 
Table 2. Research studies investigating access to joint replacement surgery according to socioeconomic status

\begin{tabular}{|c|c|c|c|c|c|}
\hline Authors & Country & Design & Study population / dataset(s) used & Socioeconomic variables & Summary of findings \\
\hline $\begin{array}{l}\text { Ackerman et al } \\
\text { (2005) [42] }\end{array}$ & Australia & $\begin{array}{l}\text { Prospective } \\
\text { cohort study }\end{array}$ & $\begin{array}{l}\text { People entering the waiting list for } \\
\text { primary THR or TKR at } 1 \text { public } \\
\text { hospital }(n=214)\end{array}$ & $\begin{array}{l}\text { Annual household income } \\
\text { Highest level of education }\end{array}$ & $\begin{array}{l}\text { People who received the lowest income had the } \\
\text { poorest HRQoL. } \\
\text { Lower education and lower income were both } \\
\text { associated with higher psychological distress. }\end{array}$ \\
\hline $\begin{array}{l}\text { Agabiti et al (2007) } \\
\text { [48] }\end{array}$ & Italy & $\begin{array}{l}\text { Retrospective } \\
\text { analysis }\end{array}$ & $\begin{array}{l}\text { Patients aged } \geq 65 \text { years undergoing } \\
\text { primary THR from } 1997-2000 \text { in } 4 \\
\text { Italian cities ( } n=6140 \text { procedures) }\end{array}$ & Area-based income index & $\begin{array}{l}\text { People in the lowest income areas were } 13 \% \text { less } \\
\text { likely to have had THR, compared with those in } \\
\text { the highest income area. Likelihood of having } \\
\text { THR was lowest for those aged } \geq 75 \text { years living in } \\
\text { the lowest income area. }\end{array}$ \\
\hline $\begin{array}{l}\text { Bang et al (2010) } \\
\text { [49] }\end{array}$ & US & $\begin{array}{l}\text { Retrospective } \\
\text { analysis }\end{array}$ & $\begin{array}{l}\text { Nationwide Inpatient Sample database } \\
\text { for } 1996 \text { to } 2005(n=8,004,571)\end{array}$ & $\begin{array}{l}\text { Income (estimated using zip } \\
\text { codes) }\end{array}$ & $\begin{array}{l}2000 \text { and } 2004 \text { (but not 1996) data showed } \\
\text { reduced odds of THR for lowest income quartile. } \\
\text { No consistent relationship between income } \\
\text { quartile and TKR rates. }\end{array}$ \\
\hline $\begin{array}{l}\text { Brennan et al } \\
(2012)[57]\end{array}$ & Australia & $\begin{array}{l}\text { Retrospective } \\
\text { analysis }\end{array}$ & $\begin{array}{l}\text { Patients who underwent primary THR } \\
\text { for OA during } 2006-2007 \text { in } 1 \text { region } \\
\text { ( } n=642 \text { procedures) }\end{array}$ & $\begin{array}{l}\text { Australian Socio-Economic } \\
\text { Index for Areas (Index of } \\
\text { Relative Socioeconomic } \\
\text { Disadvantage) }\end{array}$ & $\begin{array}{l}\text { No significant difference in THR utilisation across } \\
\text { SES quintiles for males or females. }\end{array}$ \\
\hline $\begin{array}{l}\text { Clement et al } \\
(2011)[58]\end{array}$ & UK & $\begin{array}{l}\text { Prospective } \\
\text { cohort study }\end{array}$ & $\begin{array}{l}\text { Patients undergoing primary THR for } \\
\text { symptomatic OA at } 1 \text { hospital from } \\
2006 \text { to } 2008(n=1312)\end{array}$ & $\begin{array}{l}\text { Deprivation (evaluated using } \\
\text { the Carstairs index) }\end{array}$ & $\begin{array}{l}\text { Greater deprivation was associated with more } \\
\text { severe symptoms pre-operatively (assessed using } \\
\text { the Oxford Hip Score). }\end{array}$ \\
\hline $\begin{array}{l}\text { Cookson et al } \\
(2007)[53]\end{array}$ & UK & $\begin{array}{l}\text { Retrospective } \\
\text { analysis }\end{array}$ & $\begin{array}{l}\text { Patients aged } \geq 45 \text { years who received } \\
\text { primary or revision THR in 1991-1992 } \\
\text { and } 2001-2002 \text { (sample size unclear) }\end{array}$ & Townsend deprivation score & $\begin{array}{l}\text { Lower rates of THR persisted among people living } \\
\text { in areas with the greatest deprivation but a } \\
\text { reduction in SES inequality over a } 10 \text {-year period } \\
\text { was evident. }\end{array}$ \\
\hline $\begin{array}{l}\text { Dieppe et al (2009) } \\
\text { [43] }\end{array}$ & $\begin{array}{l}12 \\
\text { European } \\
\text { countries }\end{array}$ & $\begin{array}{l}\text { Multi-centre } \\
\text { prospective } \\
\text { cohort study }\end{array}$ & $\begin{array}{l}\text { Patients undergoing primary THR at } \\
20 \text { orthopaedic centres }(n=1327)\end{array}$ & $\begin{array}{l}\text { Qualifications after school } \\
\text { Employment status }\end{array}$ & $\begin{array}{l}\text { Lack of further qualifications after leaving school } \\
\text { and retiring early were associated with greater } \\
\text { disease severity before surgery. }\end{array}$ \\
\hline $\begin{array}{l}\text { Dixon et al (2004) } \\
\text { [52] }\end{array}$ & UK & $\begin{array}{l}\text { Retrospective } \\
\text { analysis }\end{array}$ & $\begin{array}{l}\text { Patients admitted to National Health } \\
\text { Service hospitals in England for THR } \\
\text { or TKR between } 1991 \text { and } 2001 \\
\text { (sample size unclear) }\end{array}$ & Townsend index of deprivation & $\begin{array}{l}\text { Greater deprivation (greater relative } \\
\text { socioeconomic disadvantage) was significantly } \\
\text { associated with lower rates of primary THR, } \\
\text { revision THR, primary TKR and revision TKR. }\end{array}$ \\
\hline $\begin{array}{l}\text { Dixon et al (2011) } \\
\text { [56] }\end{array}$ & Australia & $\begin{array}{l}\text { Retrospective } \\
\text { analysis }\end{array}$ & $\begin{array}{l}\text { Primary THR and TKR data extracted } \\
\text { from the National Hospital Morbidity } \\
\text { Database for 2006-2007 where the }\end{array}$ & Index of Disadvantage & $\begin{array}{l}\text { The most disadvantaged quintile had lower rates } \\
\text { of THR, compared with the least disadvantaged } \\
\text { quintile, but higher rates of TKR. }\end{array}$ \\
\hline
\end{tabular}




\begin{tabular}{|c|c|c|c|c|c|}
\hline Authors & Country & Design & Study population / dataset(s) used & Socioeconomic variables & Summary of findings \\
\hline & & & $\begin{array}{l}\text { principal diagnosis was arthritis } \\
\text { ( } \mathrm{n}=46,217 \text { procedures) }\end{array}$ & & \\
\hline \multirow[t]{2}{*}{$\begin{array}{l}\text { Fitzpatrick et al } \\
\text { (2004) [26] }\end{array}$} & \multirow[t]{2}{*}{ UK } & \multirow[t]{2}{*}{$\begin{array}{l}\text { Cross-sectional } \\
\text { study }\end{array}$} & \multirow{2}{*}{$\begin{array}{l}\text { Patients undergoing THR in } 5 \text { English } \\
\text { health regions between } 1996 \text { and } \\
1997 \text { (13,343 procedures) }\end{array}$} & $\begin{array}{l}\text { Funding type (public vs } \\
\text { private) }\end{array}$ & $\begin{array}{l}\text { Public patients were over } 12 \text { times more likely to } \\
\text { wait } \geq 6 \text { months for THR. }\end{array}$ \\
\hline & & & & $\begin{array}{l}\text { Housing tenure (own house, } \\
\text { rent privately, rent publicly or } \\
\text { other) }\end{array}$ & $\begin{array}{l}\text { Housing tenure was not associated with waiting } \\
\text { times for surgery. }\end{array}$ \\
\hline $\begin{array}{l}\text { Gaudet et al (2007) } \\
\text { [65] }\end{array}$ & Canada & $\begin{array}{l}\text { Cross-sectional } \\
\text { study }\end{array}$ & $\begin{array}{l}\text { Patients with OA scheduled to have } \\
\text { THR surgery in } 5 \text { tertiary hospitals } \\
(n=161)\end{array}$ & $\begin{array}{l}\text { Occupation category (manual, } \\
\text { non-manual or mixed) }\end{array}$ & $\begin{array}{l}\text { No relationship between occupation category and } \\
\text { waiting time for surgery. }\end{array}$ \\
\hline $\begin{array}{l}\text { Hawker et al (2002) } \\
\text { [40] }\end{array}$ & Canada & $\begin{array}{l}\text { Mixed methods } \\
\text { population-based } \\
\text { survey ( } 3 \\
\text { phases) }\end{array}$ & $\begin{array}{l}\text { People aged } \geq 55 \text { years with potential } \\
\text { need for hip or knee arthroplasty } \\
\text { ( } n=456 \text { in Phase III of the study) }\end{array}$ & $\begin{array}{l}\text { Highest level of education } \\
\text { Annual household income }\end{array}$ & $\begin{array}{l}\text { Less education and lower income were } \\
\text { associated with greater potential unmet need for } \\
\text { arthroplasty. }\end{array}$ \\
\hline $\begin{array}{l}\text { Hawkins et al } \\
\text { (2011) [50] }\end{array}$ & US & $\begin{array}{l}\text { Retrospective } \\
\text { analysis }\end{array}$ & $\begin{array}{l}\text { OA patients with Medicare supplement } \\
\text { plan insurance provided by } \\
\text { UnitedHealthcare with at least } 1 \\
\text { medical claim from } 2006-2007 \\
(n=529,652)\end{array}$ & $\begin{array}{l}\text { Income level (estimated using } \\
\text { zip codes and Census data) }\end{array}$ & $\begin{array}{l}\text { Patients in the } 2 \text { lowest income categories had } \\
\text { significantly lower rates of THR/TKR. }\end{array}$ \\
\hline $\begin{array}{l}\text { Jenkins et al (2009) } \\
\text { [59] }\end{array}$ & UK & Prospective audit & $\begin{array}{l}\text { Consecutive patients undergoing } \\
\text { unilateral THR at } 1 \text { hospital from } 1998 \\
\text { to } 2005(n=1865)\end{array}$ & $\begin{array}{l}\text { Scottish Index of Multiple } \\
\text { Deprivation }\end{array}$ & $\begin{array}{l}\text { People in the greatest deprivation quintile had } \\
\text { poorer pre-operative clinical status and worse pre- } \\
\text { operative physical and mental health scores. }\end{array}$ \\
\hline $\begin{array}{l}\text { Judge et al (2009) } \\
\text { [54] }\end{array}$ & UK & $\begin{array}{l}\text { Retrospective } \\
\text { analysis }\end{array}$ & $\begin{array}{l}\text { All hip and knee replacement } \\
\text { surgeries performed in } 2002 \text { (from } \\
\text { Hospital Episode Statistics database) } \\
\text { ( } \mathrm{n}=\text { not provided) }\end{array}$ & Index of Multiple Deprivation & $\begin{array}{l}\text { People in the most deprived quintile had the } \\
\text { lowest rates of THR and a small increase in TKR } \\
\text { rates (marginally significant). }\end{array}$ \\
\hline $\begin{array}{l}\text { Judge et al (2010) } \\
\text { [55] }\end{array}$ & UK & $\begin{array}{l}\text { Retrospective } \\
\text { analysis }\end{array}$ & $\begin{array}{l}\text { Patients aged } \geq 50 \text { years who needed } \\
\text { THR or TKR in } 2002-2003 \text { and those } \\
\text { who received primary THR or TKR in } \\
2002 \text { ( } n=\text { not provided) }\end{array}$ & Index of Multiple Deprivation & $\begin{array}{l}\text { Significantly reduced provision of THR and TKR, } \\
\text { (relative to need) with increasing deprivation } \\
\text { (approximately } 70 \% \text { reduced provision for the } \\
\text { most deprived areas). }\end{array}$ \\
\hline \multirow[t]{2}{*}{$\begin{array}{l}\text { Kelly et al (2002) } \\
\text { [44] }\end{array}$} & \multirow[t]{2}{*}{ Canada } & \multirow[t]{2}{*}{$\begin{array}{l}\text { Prospective } \\
\text { cohort study }\end{array}$} & \multirow{2}{*}{$\begin{array}{l}\text { Patients waiting for THR or TKR } \\
\text { between } 1995 \text { and } 1997 \text { in } 1 \text { health } \\
\text { region }(n=553)\end{array}$} & $\begin{array}{l}\text { Education } \\
\text { Work status (full time or other) }\end{array}$ & \multirow[t]{2}{*}{$\begin{array}{l}\text { Waiting time for surgery did not differ according to } \\
\text { education, work status or residence type. }\end{array}$} \\
\hline & & & & Residence type & \\
\hline \multirow[t]{2}{*}{$\begin{array}{l}\text { Lofvendahl et al } \\
\text { (2005) [38] }\end{array}$} & \multirow[t]{2}{*}{ Sweden } & \multirow{2}{*}{$\begin{array}{l}\text { Multi-centre } \\
\text { retrospective } \\
\text { study }\end{array}$} & \multirow{2}{*}{$\begin{array}{l}\text { People who received THR, back } \\
\text { surgery or knee arthroscopy for } \\
\text { meniscus lesions }\end{array}$} & $\begin{array}{l}\text { Working status (working or not } \\
\text { working) }\end{array}$ & \multirow{2}{*}{$\begin{array}{l}\text { There was no relationship between working status } \\
\text { and waiting time for THR. There was a trend } \\
\text { towards longer waiting times for those with less }\end{array}$} \\
\hline & & & & Education & \\
\hline
\end{tabular}




\begin{tabular}{|c|c|c|c|c|c|}
\hline Authors & Country & Design & Study population / dataset(s) used & Socioeconomic variables & Summary of findings \\
\hline & & & & & education, but this was not significant. \\
\hline $\begin{array}{l}\text { Mahomed et al } \\
\text { (2003) [63] }\end{array}$ & US & $\begin{array}{l}\text { Retrospective } \\
\text { analysis }\end{array}$ & $\begin{array}{l}\text { People from the US Medicare } \\
\text { population aged } \geq 65 \text { years residing in } \\
\text { the US who received primary THR or } \\
\text { revision THR between } 1995 \text { and } 1996 \\
\text { ( } n=61,568 \text { for primary THR and } \\
n=13,483 \text { for revision THR) }\end{array}$ & $\begin{array}{l}\text { Medicaid supplementation } \\
\text { (indicating low income) }\end{array}$ & $\begin{array}{l}\text { Those receiving Medicaid supplements had lower } \\
\text { rates of primary THR and revision THR. }\end{array}$ \\
\hline $\begin{array}{l}\text { Mahomed et al } \\
(2005)[64]\end{array}$ & US & $\begin{array}{l}\text { Retrospective } \\
\text { analysis }\end{array}$ & $\begin{array}{l}\text { People from the US Medicare } \\
\text { population aged } \geq 65 \text { years who } \\
\text { received primary TKR or revision TKR } \\
\text { in } 2000 \text { ( } n=124,986 \text { for primary TKR } \\
\text { and } n=11,726 \text { for revision TKR) }\end{array}$ & $\begin{array}{l}\text { Medicaid supplementation } \\
\text { (indicating poverty-level } \\
\text { income) }\end{array}$ & $\begin{array}{l}\text { Those receiving Medicaid supplements had lower } \\
\text { rates of primary TKR and revision TKR. }\end{array}$ \\
\hline $\begin{array}{l}\text { Makela et al (2010) } \\
\text { [51] }\end{array}$ & Finland & $\begin{array}{l}\text { Retrospective } \\
\text { analysis }\end{array}$ & $\begin{array}{l}\text { Patients receiving primary THR for } \\
\text { primary OA or OA secondary to DDH } \\
\text { between } 1998 \text { and } 2005 \text {, drawn from } \\
\text { the Hospital Discharge Register } \\
\text { ( } n=44,093 \text { procedures) }\end{array}$ & $\begin{array}{l}\text { Average regional income } \\
\text { (estimated by state taxation) }\end{array}$ & $\begin{array}{l}\text { No association between average regional income } \\
\text { and incidence of THR. }\end{array}$ \\
\hline \multirow[t]{2}{*}{$\begin{array}{l}\text { Melzer et al (2003) } \\
\text { [41] }\end{array}$} & \multirow[t]{2}{*}{ US } & \multirow{2}{*}{$\begin{array}{l}\text { Retrospective } \\
\text { study (interviews } \\
\text { conducted with } \\
\text { relatives or } \\
\text { contacts of } \\
\text { decedents) }\end{array}$} & \multirow{2}{*}{$\begin{array}{l}\text { People aged } \geq 65 \text { years who had died } \\
\text { in the US in } 1993 \text { drawn from the } \\
\text { National Mortality Followback Survey } \\
(n=6586)\end{array}$} & \multirow{2}{*}{$\begin{array}{l}\text { Highest level of education } \\
\text { Medicaid coverage (marker of } \\
\text { poverty) }\end{array}$} & $\begin{array}{l}\text { Lower education was associated with lower odds } \\
\text { of having a THR but not TKR. }\end{array}$ \\
\hline & & & & & $\begin{array}{l}\text { Medicaid coverage was associated with higher } \\
\text { odds of having a THR but not TKR. }\end{array}$ \\
\hline $\begin{array}{l}\text { Milner et al (2004) } \\
\text { [21] }\end{array}$ & UK & $\begin{array}{l}\text { Population-based } \\
\text { survey }\end{array}$ & $\begin{array}{l}\text { People aged } \geq 65 \text { years from } 2 \text { Health } \\
\text { Authority regions ( } n=11,214 \text { ) including } \\
388 \text { individuals in need of hip } \\
\text { replacement }\end{array}$ & $\begin{array}{l}\text { Deprivation (assessed by } \\
\text { receipt of means-tested } \\
\text { welfare benefits) }\end{array}$ & $\begin{array}{l}\text { Deprivation was a significant predictor of unmet } \\
\text { need for THR; this group was twice as likely to } \\
\text { need surgery but less likely to be on a waiting list. }\end{array}$ \\
\hline \multirow{2}{*}{$\begin{array}{l}\text { Mnatzaganian et al } \\
\text { (2011) [75] and } \\
\text { reply (2012) [45] }\end{array}$} & \multirow[t]{2}{*}{ Australia } & \multirow{2}{*}{$\begin{array}{l}\text { Population-based } \\
\text { survey }\end{array}$} & \multirow{2}{*}{$\begin{array}{l}\text { Sample drawn from the Health In Men } \\
\text { Study involving men aged 65-83 living } \\
\text { in Perth }(n=11,388)\end{array}$} & \multirow{2}{*}{$\begin{array}{l}\text { Relative social disadvantage } \\
\text { (Australian Socio Economic } \\
\text { Index For Areas) } \\
\text { Level of education }\end{array}$} & $\begin{array}{l}\text { Higher SES was associated with increasing rates } \\
\text { of TJR, in particular for the } 70-74 \text { age group. }\end{array}$ \\
\hline & & & & & $\begin{array}{l}\text { Education category was not associated with } \\
\text { having TJR. }\end{array}$ \\
\hline $\begin{array}{l}\text { Murray et al (2006) } \\
\text { [60] }\end{array}$ & UK & $\begin{array}{l}\text { Multi-centre } \\
\text { prospective } \\
\text { cohort study }\end{array}$ & $\begin{array}{l}\text { People undergoing TKR between } \\
1992 \text { and } 1997 \text { in the Northern Region } \\
(n=2506)\end{array}$ & Townsend score & $\begin{array}{l}\text { No relationship was identified between deprivation } \\
\text { score and pre-operative knee function or HRQoL. }\end{array}$ \\
\hline $\begin{array}{l}\text { Rahman et al } \\
\text { (2011) [25] }\end{array}$ & Canada & $\begin{array}{l}\text { Prospective } \\
\text { cohort study }\end{array}$ & $\begin{array}{l}\text { Patients newly diagnosed with OA } \\
\text { from } 1996 \text { to } 1998 \text { in British Columbia } \\
(n=34,420)\end{array}$ & $\begin{array}{l}\text { Socioeconomic status (based } \\
\text { on using postal codes and } \\
\text { Census data to estimate }\end{array}$ & $\begin{array}{l}\text { The highest SES quintile had the greatest } \\
\text { likelihood of having a TJR during the follow-up } \\
\text { period. }\end{array}$ \\
\hline
\end{tabular}




\begin{tabular}{|c|c|c|c|c|c|}
\hline Authors & Country & Design & Study population / dataset(s) used & Socioeconomic variables & Summary of findings \\
\hline & & & & neighbourhood-level income) & \\
\hline $\begin{array}{l}\text { Skinner et al (2006) } \\
\text { [47] }\end{array}$ & US & $\begin{array}{l}\text { Retrospective } \\
\text { analysis }\end{array}$ & $\begin{array}{l}\text { Medicare enrollees in } 2000 \text { aged } \geq 65 \\
\text { years }(n=27,494,659) \text { and data drawn } \\
\text { from the National Health and Nutrition } \\
\text { Examination Survey (NHANES III) for } \\
\text { people with OA aged } \geq 60 \text { years } \\
(n=1926)\end{array}$ & $\begin{array}{l}\text { Income (estimated by linking } \\
\text { zip codes to Census data) }\end{array}$ & $\begin{array}{l}\text { Overall, there was no association between income } \\
\text { and TKR rates but after adjusting for region, } \\
\text { higher income groups had higher rates of TKR. } \\
\text { There was a similar prevalence of OA across } \\
\text { income categories. }\end{array}$ \\
\hline $\begin{array}{l}\text { Steel et al (2006) } \\
\text { [46] }\end{array}$ & UK & $\begin{array}{l}\text { Cross-sectional } \\
\text { analysis of } \\
\text { population-based } \\
\text { longitudinal study }\end{array}$ & $\begin{array}{l}\text { People aged } \geq 60 \text { years from the } \\
\text { English Longitudinal Study of Ageing } \\
(\mathrm{n}=7101)\end{array}$ & Total non-pension wealth & $\begin{array}{l}\text { Need for THR or TKR was over } 3 \text { times higher for } \\
\text { the poorest quintile, compared with the wealthiest } \\
\text { quintile although odds of ever receiving surgery } \\
\text { were similar. The deprivation gradient was no } \\
\text { longer evident after excluding people with major } \\
\text { contraindications for surgery. }\end{array}$ \\
\hline $\begin{array}{l}\text { Woolhead et al } \\
\text { (2002) [62] }\end{array}$ & UK & Qualitative study & $\begin{array}{l}\text { People on the waiting list for TKR } \\
(n=25)\end{array}$ & Not applicable & $\begin{array}{l}\text { Themes arising: perception that access to TKR } \\
\text { should be based on factors such as pain, mobility } \\
\text { and employment but that surgery provision could } \\
\text { be unfairly determined by access to private health } \\
\text { care. }\end{array}$ \\
\hline $\begin{array}{l}\text { Yong et al (2004) } \\
\text { [20] }\end{array}$ & UK & $\begin{array}{l}\text { Cross-sectional } \\
\text { population-based } \\
\text { study with follow- } \\
\text { up healthcare } \\
\text { data linkage }\end{array}$ & $\begin{array}{l}\text { People aged } \geq 65 \text { years from } 2 \text { Health } \\
\text { Authority regions }(n=11,214) \text { including } \\
574 \text { individuals in need of knee } \\
\text { replacement }\end{array}$ & $\begin{array}{l}\text { Deprivation (assessed by } \\
\text { receipt of means-tested } \\
\text { welfare benefits) }\end{array}$ & $\begin{array}{l}\text { Deprivation was a significant predictor of unmet } \\
\text { need for TKR; this group was twice as likely to } \\
\text { need surgery but less likely to be on a waiting list } \\
\text { and similarly likely to have had surgery. }\end{array}$ \\
\hline
\end{tabular}

DDH: developmental dysplasia of the hip; OA: osteoarthritis; SES: socioeconomic status; THR: total hip replacement; TJR: total joint replacement; TKR: total knee replacement 


\section{University Library}

\section{- M M I N E R VA A gateway to Melbourne's research publications}

Minerva Access is the Institutional Repository of The University of Melbourne

Author/s:

Ackerman, IN;Busija, L

Title:

Access to self-management education, conservative treatment and surgery for arthritis according to socioeconomic status

Date:

2012-10-01

Citation:

Ackerman, I. N. \& Busija, L. (2012). Access to self-management education, conservative treatment and surgery for arthritis according to socioeconomic status. BEST PRACTICE \& RESEARCH IN CLINICAL RHEUMATOLOGY, 26 (5), pp.561-583. https://doi.org/10.1016/ j.berh.2012.08.002.

Persistent Link:

http://hdl.handle.net/11343/58844 